\title{
Voices of Atayal People: Indigenous Cultural Memory in Modern Taiwan Society
}

\author{
Yer J. Thao \\ Full Professor at Portland State University, \\ College of Education, USA.
}

\begin{abstract}
When talking about Indigenous culture in the $21^{\text {st }}$ century, it is important to understand the Taiwan Indigenous People and their ways of cultural practices. This study used ethnographic inquiry as a qualitative approach for a total of 11 people from an aboriginal tribe called, Tayal (Atayal) in northern Taiwan. Data sources include: (1) Tape-recording in Mandarin Chinese, Tayal language, and English from the research participants; (2) Community event observations; and (3) one-on-one interviews. This study revealed that preservation of Tayal heritage, language, culture and social lifestyle structure in the $21^{\text {st }}$ century and beyond is a major concern and deeply important to Tayal communities and individuals. An effort to construct an authentic Tayal traditional culture education program seems to have significant benefits for not only Tayal children, families, communities, but for the Taiwanese society as well.
\end{abstract}

Keywords: Indigenous, Aboriginal, Oral Culture, Diversity, and Taiwanese.

\section{INTRODUCTION}

This study examines how the Taiwan Indigenous Peoples maintain their oral culture knowledge and identity amidst an evolving modern society. Currently, the Taiwan government has recognized sixteen Aboriginal tribes. "Atayal" is the official term recognized by the Taiwanese government for the Atayal Nation. This study concentrates on the Atayal, or "Tayal," communities. I am using the spelling of "Tayal" rather than "Atayal" because I discovered it from my fieldwork that the spelling of Atayal is not preferable by the majority of Elders interviewed. From their inside, emic, perspective, they speak Sekoleg and Tseole. Therefore, Tayal represents a designation that is larger than an ethnolinguistic identity: its history, language and culture. Ethnolinguistically, the language of Indigenous Taiwanese with a multiplicity of diverse but related dialects show a clear relationship to the Austronesian language family (Rau, 1992; Hung, 2002; Lee, 2013). Lee (2013) adds that Tayal language has phonetic features of pronunciation like the glottal stop and voiceless alveolar, which are not conveyed in the spelling. One Elder attempted to convey this correct pronunciation and actually wrote it for me to see without a letter " $A$ " in front of the letter "T" to give the idea of that glottal stop (Personal Communication). A document I retrieved from Digital Museum of Taiwan Indigenous Peoples described that the term "Tayal" was adopted historically to refer using one dialect to refer to a more complex group. Therefore, Tayal was broken down into two language groups called Atayal and Sedek. The document explained:

The name "Tayal" originally indicated the group with the largest population among the entire "Tayal" ethnic group, which includes the Sekolek and Tseole groups under the Atayal sub-tribe, and means "people who use the same Atayal language and have common cultural features, such as facial tattoos and places of origin." But in different dialects, the term "Tayal" has different pronunciations, such as Atayal, Tayal, Tayen or Tayan. "Tayal" has long been applied to both the Atayal sub-tribe and the Sedek subtribe. However, no matter whether the term is Tayal, Atayal, Tayen or Tayan, it is not a term of self-address for the Sedek sub-tribe (http://www.dmtip.gov.tw/Eng/Atayal.htm Retrieved, May 20, 2016). 
This mis-designation is familiar to my own experience as a member of the Mong ethnolinguistic group. We were lumped together with a larger designation, Hmong, by the linguistically insensitive American bureaucracy. But, it must be said, at least the American system of classification did not perpetuate the Lao (Meo) and Chinese (Miao) external, derogatory designations (Thao, 2006).

There are not many oral traditional culture ethnic groups left living in either Taiwan or the world (Thao, 2006; Thao, 2014). Today, the Tayal people in Taiwan still maintain strong traditional culture practices as daily lifestyle. Tayal is the largest tribe of all 16 tribes inside a larger designation of the Amis tribe (Kun-hui, 2012; Yen and Chen, 2013) with a total population numbering 85, 888 in 2014 (Digital Museum of Taiwan Indigenous People, 2016). Chai (1967) noted that the Taiwan Indigenous population was 8,000 during the time the Dutch occupied Taiwan in the 1600 s. It grew to 50,000 in the era that the Japanese colonized Taiwan, and now it reaches over 530,000, of which the Tayal make up of $15.9 \%$ of the Taiwan Aboriginal population (Digital Museum of Taiwan Indigenous People, 2016). As I encountered the profound beauty of Tayal culture, I was inexorably drawn into the necessity of witnessing and recording this compelling tradition before it is submerged beneath the increasing waves of modernization. Yoshimura (2007) also notes that the Taiwan indigenous people of Wulia Tayal have a long history and a rich cultural tradition. Today, however, the Wulia Tayal community has lost many of their important traditional cultural values but one indicator of persistence exists with Tayal women who literally and figuratively restore and reinterpret tradition through weaving (Yoshimura, 2007). Yoshimura and Wall (2010) added that the Wulia Tayal women offer weaving sessions to help the younger generation of Tayal as well as tourists learn about important values of Tayal culture. Since Taiwan is a willing player in this world of globalizing modernization, I am interested in doing my research with the Tayal communities to have an understanding of their traditional culture struggles before they are all seriously transformed by the experience of contact with modernizing culture.

\section{LITERATURE REVIEW ON THE TAYAL PEOPLE}

According to (Wang, 2012), he defined the Tayal culture to be "skillful in hunting and fighting and normally requires a fearless heart to do that" (pp. 7-8). The Tayal have a cultural value for "braveness." The men are hunters and women are weavers (Wang, 2012; Yoshimura, 2007). Tayal people are well known for their facial tattoos. The tattoo for the men signifies hunting skills and courage. The women's tattoo signifies skillfulness in weaving and cultivation. Tattoos signify maturity before marriage (Yoshimura, 2007; Chen, 2007; Lin, 2008; Yoshimura and Wall, 2010; Shih, 2010; Hose, Schaub \& Bremer, 2010; Wang, 2012; Yen and Chen, 2013).

It is very important to understand the barriers that the Tayal people struggle with while they are trying to maintain the rights to protect and preserve their traditional language and culture in $21^{\text {st }}$ century Taiwanese society. There are several underlying problems described in the literature: differing social-cultural structure and educational systems, government policy, and the influence of technological change are dilemmas Tayal communities encounter. The Tayal people are seeking every possible way to work with the Taiwan government for SelfGovernance so they can protect their land and natural resources (Yoshimura, 2007; Kuan, 2009; Youshimura and Wall, 2010; Reid, 2010; Kun-hui, 2012; Yen and Chan, 2013; Sheu and Huang, 2014). Reid (2010) stated that years of political conflict between the Taiwan government and the Smangus community led Smangus to establish a very strong selfgoverning system. Similarly, the Tayal use their traditional cultural governing system called (Gaga) as a model to restore the rights to protect their people, culture and land (Sheu and 
Huang, 2014; Yen and Chen, 2013). This self-governing was established for the best interest of the Tayal people to protect, serve, and preserve their rights, customs, culture and language.

Recent genetic and linguistic studies map indigenous Taiwanese Peoples earliest history linking them to the Austronesian family (Chai, 1967; Rau, 1992; Keating, 2011; Lee, 2013; Hu, H., Tseng, R., Lin, C., Ming, L., \& Ikeuchi, K. (2014). Hu, H., Tseng, R., Lin, C., Ming, L., \& Ikeuchi, K. (2014) concluded their study from the Taiwan Indigenous Tribes of Yami and Tao that with persistent practices in regards to ancestral gardens, cultivars, and wildlife, the ancestral ideas of Austronesian TEK such as cropping and entranced agroforestry illustrate a meaningful mindset against social and environmental degradation. Similarity, we might contextualize the Tayal people within cultural forces normative for Taiwan Indigenous communities and the larger Austronesian cultures. The Tayal people were widely spread through northern and central Taiwan. They established their villages on high elevation within the mountain ranges (Chai, 1967; Yoshimura, 2007; Chen, 2007; Lin, 2008; Tang and Tang, 2010; Yoshimura and Wall, 2010; Kun-hui, 2012; Yen and Chen, 2013; Hsiao, 2016).

During the Japanese colonization/occupation of Taiwan from 1895-1945, they forced the Taiwan Indigenous to move into the city and placed their children into schools with the goals of assimilation to Japanese culture and the adoption of Japanese language (Hose, Schaub \& Bremer, 2010; Yoshimura and Wall, 2010; Munsterhjelm, 2004). During this time, the Japanese viewed the Tayal people to be savage, barbarians, and dangerous. Japanese stereotyped Tayal traditional cultural practice, especially the headhunting ritual. Japanese established a law to stop the Tayal's hunting tradition (Wang, 2012; Sheu and Huang, 2014; Digital Museum of Taiwan Indigenous People, 2016; Fang, Hu and Lee, 2016). Therefore, the basis of Tayal culture, language and social life-style was aggressively and ethnocentrically challenged from the day foreigners arrive. This dates from the Spanish and Dutch between 1624 to 1642, the growth of Chinese migration from Mainland China from 1644 to 1959, and the Japanese colonization from 1895 to1945, as well as Christian missionaries in early1900s to late1940s, and finally with the construction of the Taiwanese state (Chai, 1967; Yoshimura, 2007; Yoshimura and Wall, 2010; Tang and Tang, 2010, Blundell, 2010; Fang, Hu and Lee, 2016).

Missionaries played a major role in Tayal communities. They gave a Romanized Phonetic Alphabet (RPA) written script for the Tayal people after WWII around 1948. Since then the Tayal orality has been significantly challenged and eroded. This written system was given to them with the intention to read and transcribe the bible (Wang, 2012). Munsterhjelm (2004) reported that a Canadian Presbyterian missionary, Dr. George Leslie Mackey was here in north Taiwan in 1872 and lived in Taiwan until he died in 1901. Dr. Mackey's collection of artifacts and research on the Taiwan Indigenous Peoples becomes a very important account. (Munsterhjelm, 2004). However, no one knows the extent of Dr. Mackey's influence on the Tayal people in the late 1800s. However, the Tayal people may have begun to have contact with the missionaries in the early part the of 1900s. Kun-hui (2012) pointed out that the pastors in one group supported advocacy for the Smangus tribe and other Tayal communities to mobilize at governmental level to have Indigenous rights policy in Taiwan.

Tayal religion was obviously subject to the forces of Christian evangelization. Before Tayal were challenged by Christianity, they had a religious cultural tradition which was guided Tayal defined by spiritual forces (Tang and Tang, 2010). These belief systems that the Tayal have are designated by the Gaga and Utux. Gaga is a way to unify their people in a kinship based system of dispute resolution, their justice system. It is a shared belief system that the Tayal inherited from their ancestors, which relies on the maintenance of strong kinship relations which create familial and social stability and cohesion (Tang \& Tang, 2010). Utux are, briefly, 
ancestral spirits whose intercession provide protection from sickness, paths for prosperity, and consistent balance and health, personal, familial, and social. Tang and Tang (2010) pointed out that as early as 1948, Christianity challenged and overtly replaced most Taiwan Indigenous tribal religions.

The Tayal lifestyle and traditional culture practice have a long history that can be traced back thousands of years if we pay closer attention to oral culture tradition. The Tayal language and cultural values were embedded in all their songs, folklores, rituals, mythologies, hunting, gathering, weaving cloths and baskets (Gluck, 2005; Yoshimura, 2007; Chen, 2007; Lin, 2008; Hsiao, 2008; Shung Ye Museum of Formosan Aborigines, 2010; Hose, Schaub \& Bremer, 2010; Hsiao, 2011; Lee, 2013; Mebow, 2016; Fang-Ming, 2016). Nowadays, some of Tayal traditional values have undergone changes in the Tayal communities. They have to adapt new survival skills in order to keep up with modern culture. Traditional skills like hunting, gathering and farming are no longer applicable for many young Tayal people. They will have to move into cities to gain new labor skills and find work (Gluck, 2005; Fang, Hu and Lee, 2015; Mebow, 2016). Hsiao (2008), Tang \& Tang (2010), Yen and Chen (2013) and Fang, Hu and Lee (2016) explained that today Tayal communities are increasingly relying on the tourism business for their income. Prior to the development of culture tourism, mushroom gathering and fruit farming were the main financial sources to enhance the Tayal communities. Therefore, Tayal will have to adapt to the skills and knowledge in modern society in order to continue to take advantage of the tourism industry (Gluck, 2005; Tang and Tang, 2010; Yoshimura and Wall, 2010; Fang, Hu and Lee, 2016). Tang and Tang (2010) added that since the early 1990s ecotourism business development has become popular and booming in Taiwan Indigenous communities. The busy traffic by tourists helps with the Tayal economy, but at same time destroys the natural environment as well as causes some tribes to lose their land to outside business developers.

\section{METHODOLOGY}

I used ethnographic inquiry as a qualitative method to participate in and observe Tayal cultural struggles with the challenges of living in modernizing Taiwanese culture. This article presents data findings and analysis of the study. Agar (1996) noted that a researcher must play in the role as a professional stranger, who enters into the world of the people he/she is working with rather than viewing them through his/her worldview. I am following this method. Cresswell (2013) added that researchers commonly use an interpersonal and behaviorally situated activity to examine a culturally contextualized problem or issue that needs to be explored.

The aim of this data analysis and presentation is to highlight the participants' responses to the research questions. All interviews were recorded into a digital voice recorder and camcorder. The responses are translated, transcribed, coded, and tallied onto data gathering collection sheets according to the theme topics. The responses draw from ten open-ended questionnaires around language, culture and socio-lifestyle values and their struggles embracing them in the $21^{\text {st }}$ century.

In this research study, I used an open-ended question to solicit responses from the participants in March, April and May of 2016. However, the 10 open-ended questions had, by definition, rather broad content and could yield multiple responses. This was a calculated risk and could be detrimental to this research. To reduce this risk, I added more questions during the conversational dialogue in the hope of getting more varied responses. Despite the follow-up questions, I encountered several setbacks through the interpreter. I hired an interpreter who is from the Tayal community for all the interviews. I noticed that the interpreter sometime struggled to frame the questions or direct the research participants to focus on the content of 
the question. Having interpreted myself for non Mong speaking friends in America, I am well aware of the potential risks.

\section{Participants}

For this study, the researcher interviewed a total of 11 individuals. The participants who graciously volunteered to participate are: The Elders who are from the Tayal communities, one Tayal university professor, and two Tayal graduate students who recently received their Masters' degree from the university. Of the eight Elders, five are males and three are females (See Table 1). All the names of the research participants are in Tayal and each name has a very special meaning. For examples, Wasing meaning black nightshade, Wagi means sunshine, and Lahuy means forest tree. Tayal's surname is taken from the father's first name. For example, with Wagi Sulong, Sulong is Wagi's father's name. In Tayal society, they do not have a clan kinship system like the Chinese, but a different equally strong kinship. The participants all are fluent in Tayal language except one. The county of residency my research participants leave in are: Hsinchu County, Taoyuan County and Maioli County in Taiwan.

Table 1

\begin{tabular}{|c|c|c|c|c|c|}
\hline Name & Age & $\begin{array}{l}\text { Language \& } \\
\text { Tribe }\end{array}$ & Gender & Education & Skill/Occupation \\
\hline Lawa Toyu & 103 & $\begin{array}{l}\text { Tseole \& } \\
\text { Maylubung } \\
\text { Surauw }\end{array}$ & Female & No Schooling & Farmer/Housewife \\
\hline Iwan Kaynu & 101 & $\begin{array}{l}\text { Tseole \& } \\
\text { Madabalai }\end{array}$ & Female & No Schooling & $\begin{array}{l}\text { Farmer/Housewife and Jew's } \\
\text { Harp Music Artist. }\end{array}$ \\
\hline Tayah Behuy & 93 & Sekoleg \& Qehuy & Male & $\begin{array}{l}\text { Japanese } \\
\text { Elementary }\end{array}$ & $\begin{array}{l}\text { Farmer, Community Leader, } \\
\text { Former Pastor and Father. }\end{array}$ \\
\hline Watan Tanga & 87 & Sekoleg \& Rahaw & Male & $\begin{array}{l}\text { Japanese } \\
\text { Elementary }\end{array}$ & $\begin{array}{l}\text { Farmer, Community Leader, } \\
\text { Former Pastor, Tayal } \\
\text { Traditional Songs Expertise, } \\
\text { Artists, Musician, Father, and } \\
\text { Aboriginal Traditional } \\
\text { Consultant. }\end{array}$ \\
\hline Masa Tohuy & 84 & Sekoleg \& Bilus & Male & $\begin{array}{l}\text { Japanese } \\
\text { Elementary }\end{array}$ & $\begin{array}{l}\text { Farmer, Community Leader, } \\
\text { Tayal Culture Expertise, and } \\
\text { Consultant. }\end{array}$ \\
\hline Donaiy Dili & 70 & $\begin{array}{l}\text { Tseole \& } \\
\text { Maibagah }\end{array}$ & Male & $\begin{array}{l}\text { Japanese } \\
\text { Junior High } \\
\text { School }\end{array}$ & $\begin{array}{l}\text { Tayal Language and Culture } \\
\text { Teacher. He is Jew's Harp } \\
\text { Making Expertise and Culture } \\
\text { Consultant. Arts \& Crafts } \\
\text { Educator. He is a singer and } \\
\text { was a retired Policy Officer. }\end{array}$ \\
\hline Wagi Sulong & 64 & Sekoleg \& Colen & Female & $\begin{array}{l}\text { Japanese } \\
\text { Elementary }\end{array}$ & $\begin{array}{l}\text { Farmer, Housewife, and } \\
\text { Traditional Musician. }\end{array}$ \\
\hline Masay Sulong & 57 & $\begin{array}{l}\text { Sekoleg \& } \\
\text { Smangus }\end{array}$ & Male & $\begin{array}{l}\text { Japanese } \\
\text { Junior High } \\
\text { School }\end{array}$ & $\begin{array}{l}\text { Farmer, Chief of Smangus } \\
\text { Community, and Sculpture and } \\
\text { Music Artists }\end{array}$ \\
\hline Masao Aki & 49 & $\begin{array}{l}\text { Sekoleg \& Chen- } \\
\text { Shi }\end{array}$ & Male & University & $\begin{array}{l}\text { Father and University } \\
\text { Professor }\end{array}$ \\
\hline Lahuy Icyeh & 36 & $\begin{array}{l}\text { Sekoleg \& } \\
\text { Smangus }\end{array}$ & Male & University & $\begin{array}{l}\text { Father/Teacher and Ecology } \\
\text { Tourism Educator and } \\
\text { Expertise }\end{array}$ \\
\hline Wasing Silan & 29 & Sekoleg \& Wulai & Female & University & $\begin{array}{l}\text { Educator/currently a doctoral } \\
\text { student }\end{array}$ \\
\hline
\end{tabular}




\section{DISCUSSION AND RESULTS}

The Tayal were humble, kind and generous. My visits to the Tayal communities were an absolutely wonderful experience. I was welcomed to their communities without any hesitation. The hospitality I received was excellent. Some trips to the communities required me to stay overnight because it was four to five hours away from Taipei to the steep mountains. It was a very difficult road trip traveling to the mountains because the road was narrow, curving up and down hills. I was invited to spend the night at the Elder's house. I did not have to worry about food and lodging. I learned that the way I was being treated is a part of Tayal culture to offer and welcome outsiders. This study of the Tayal people unveiled similar profound struggles and concerns about maintaining language, culture, religion, and social lifestyle shared by Indigenous and oral cultural tradition people groups around the world like the Native American Indian in the United States, Maori people in New Zealand and the Mong people (Cajete, 1994; Thao, 2006; Smith-Tuhiwai, 2012).

Tayal Important Tradition and Culture Elements. The Tayal people have many cultural identifications that they do not want see all get lost. According to the Elders, Tayal language must be known and kept in the culture. One Elder stated, "If Tayal language die then we, Tayal no longer have a nation" (Personal Communication, April 2016). Tayal language is very special because it consists of many language groups spoken from tribe to tribe. As you can see from Table 1, there are two language groups: Sekoleg and Tseole. In addition, it is very important to keep the Jew's Harp music (see picture 1), weaving baskets, weaving cloths, and family social lifestyle structure. Is highly regarded in the Tayal family tradition for honoring and respecting the elders and parents.

\section{Picture 1: Harp performance at Ching An Elementary School with Elder Iwan Kaynu, Teacher Donaiy Dili and a student.}

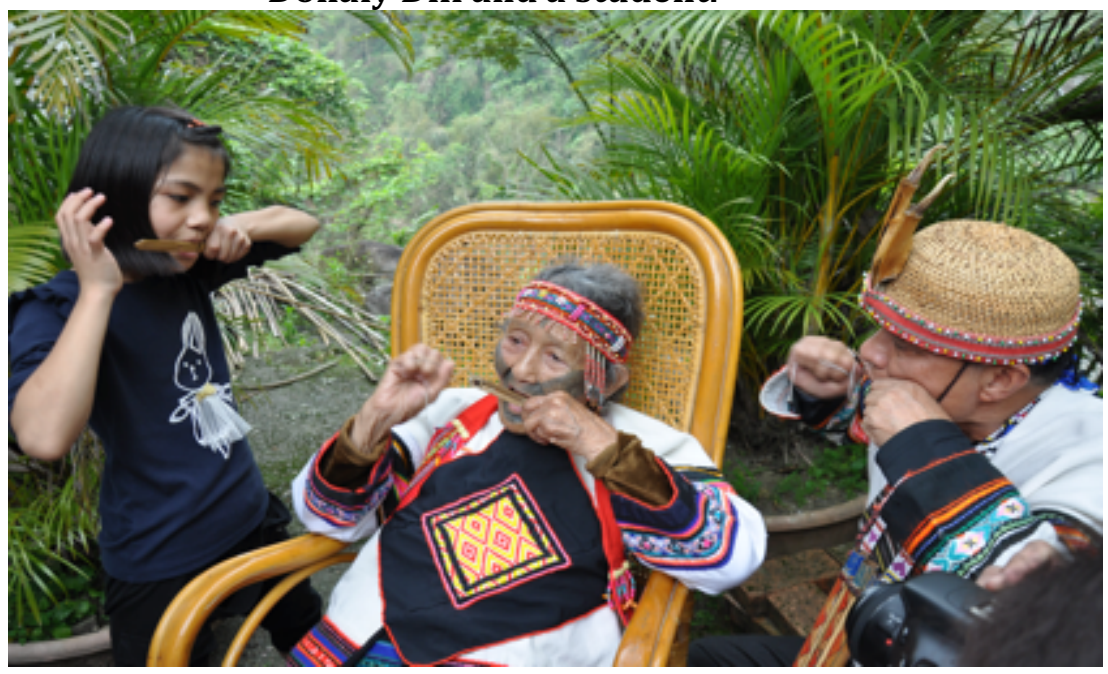

The Tayal names are very important. Tayal carry a patronymic system in their names. Tayal can be identified by a surname, which is the first name of the father and language group spoken. The name and language indicators help other Tayal to identify him/her immediately and quickly become accepted into a family kin with respect. The Tayal Elders worry that this tradition is no longer understood and embraced by Tayal children. Nowadays, Tayal children do not have a patronymic name but rather have taken a Chinese or Western name. Increasingly, this name changing has become a major concern to Tayal Elders. The Tayal people have taken Chinese names for school purposes and work so they can avoid discrimination in Taiwanese society. Tayal names are becoming invisible in the modern culture. For example, Elder Donaiy Dili has a Chinese name called Liang Yu Shui. When he was 
in school and worked as a police officer he only used his Chinese name. Now working as a Tayal language and culture teacher, he can reclaim his Tayal name. People only know him by Liang Yu Shui outside of the Tayal communities. A Tayal is taking a different name considered disrespectful to Tayal culture. Therefore, family unification will be destroyed based if kinship and belief in the moral principles from Gaga and Utux are lost by Tayal children. A moral principle of Utux belief is to have love and respect for the parents. If not then there will be a bad curse for not being able to have prosperity and happiness.

Ceremonials for hunting, farming, wedding and ancestral worship are important to the livelihood of the Tayal people. They will have to let some parts of these rituals go. Elder Masay Sulong expressed:

Now a day, Tayal people have their wedding ceremony in the church. If they want to have a traditional ceremony then it still can be done at home, but we still have to do it at the church as part of our Christian belief. This is why my son's wedding ceremony takes place in the church. There will be a traditional meal and gathering at my house and a big banquet at the restaurant for the wedding as well (Personal Communication, April 2016).

I attended all the events on Elder Masay's son's wedding and witnessed the culture transformation that took place. See Pictures $2,3 \& 4$. The way to have a wedding banquet at a modern restaurant considered a huge culture changes for the Tayal people.

Picture 2: Bride and Groom placed their hands on the bible to make a promise to God on their marriage and love relationship.

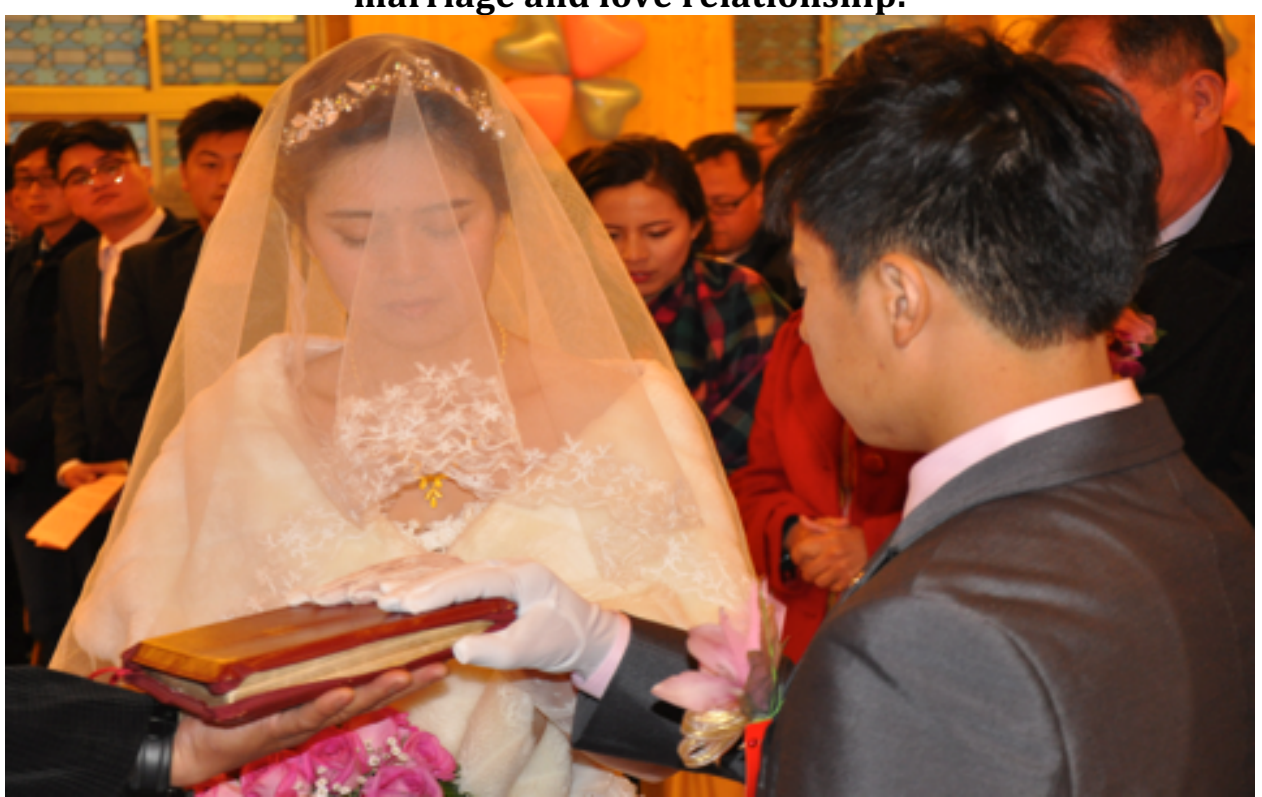


Picture 3: People gathering for a meal and celebrating at Elder Masay Sulong's house during his son's wedding.

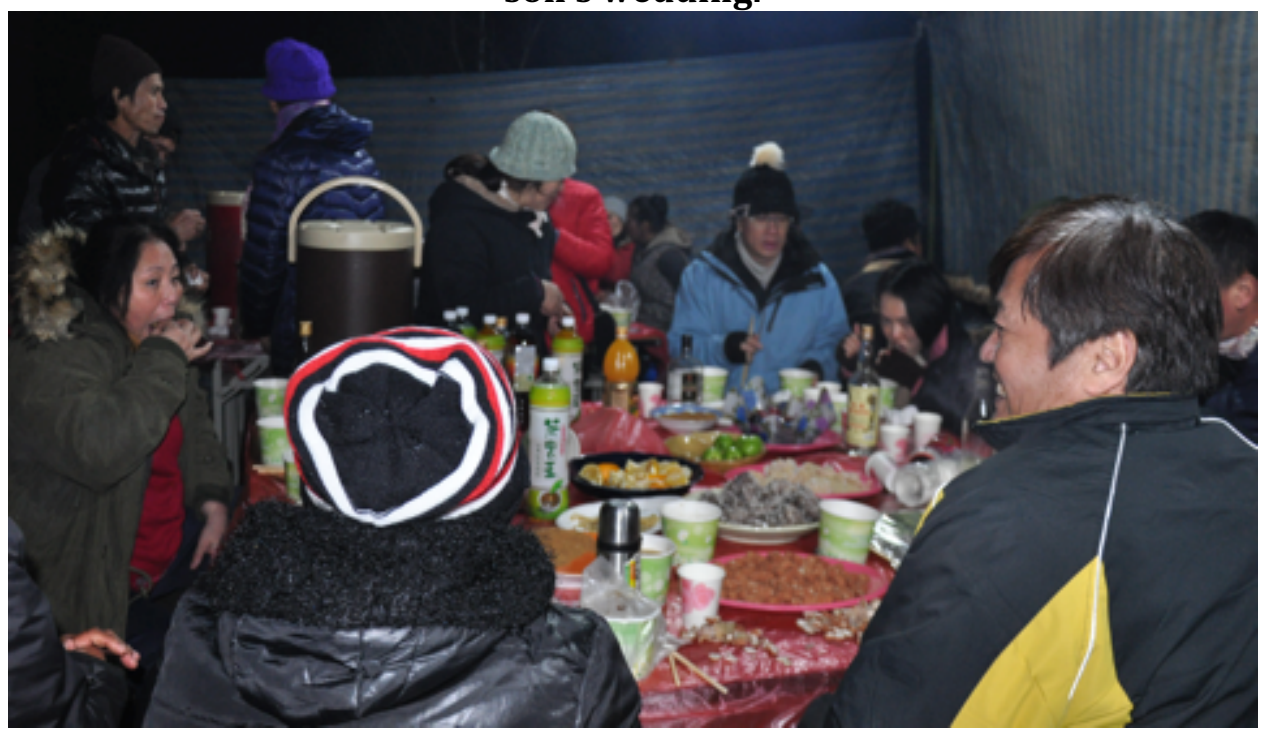

Picture 4: Banquet at a modern restaurant for Elder Masay Sulong son's wedding.

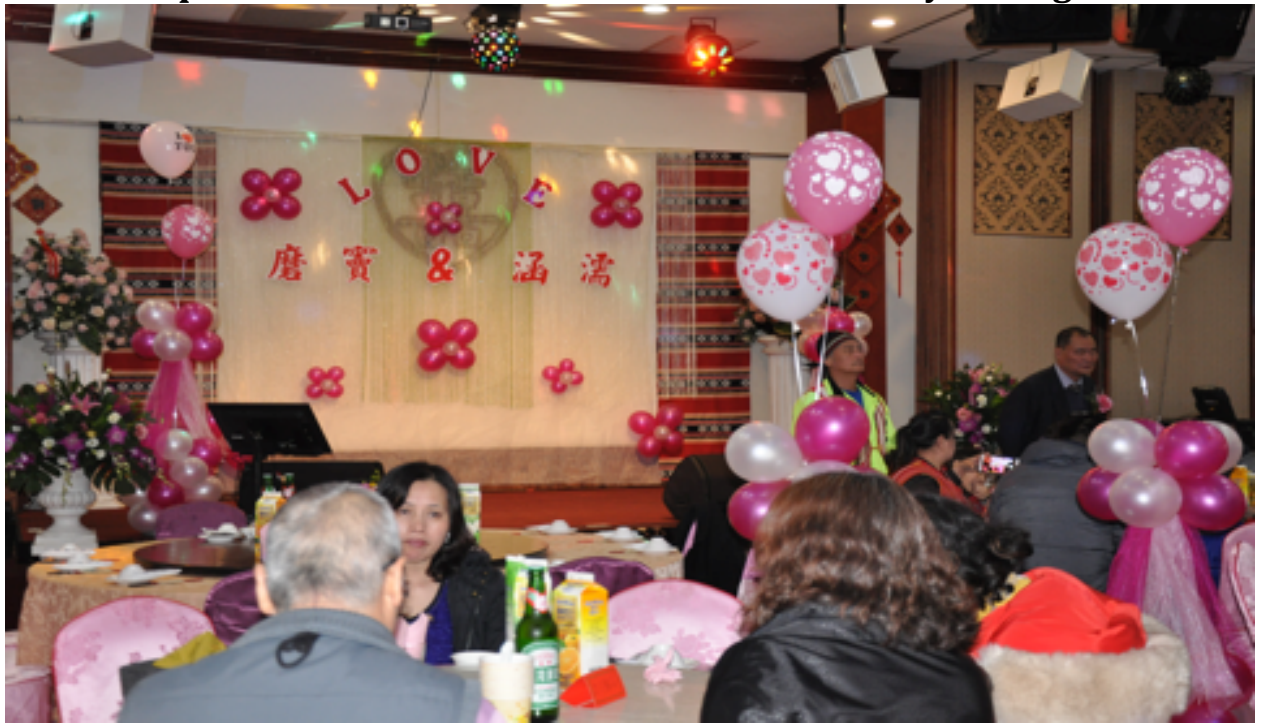

Reactions in general to what the Tayal language and culture educational programs are like at school and in the Taiwanese society for this $21^{\text {st }}$ century. Since the Taiwan Martial Law lifted in 1987, opportunities have opened for the Indigenous People of Taiwan to have a voice at the governmental level (Blundell, 2012). From the beginning of 1990 to 2005, the Taiwan government made strong efforts to recognize the Taiwan Indigenous Peoples and cooperated with different tribes to establish policy for culture preservation and Indigenous rights (Hsiao, 2008; Blundell, 2012; Kun-hui, 2012; Reid, 2010). Blundell (2012) stated that since the beginning of 1990, the constitutional reform movement put Taiwan Indigenous Peoples in a good position. Indigenous communities began to gain power and to have a voice in the government for their rights. The Tayal communities have more autonomy to claim their land and protect their language and culture (Kun-hui, 2012; Reid, 2010). The Tayal Smangus tribe at God Village successfully established a self-supporting and self-governing system within the Smangus community (Reid, 2012). Elder Masay Sulong and Lahuy Icyeh from Smangus shared the community's success by first acknowledging the efforts from the entire community members who were working very hard collectively and all the supporters from other tribes. Together, they worked with Taiwan legislators and government agencies to gain success for 
the Smangus tribe to restore their justice, resources, beauty and harmony in cultural tradition. After Lahuy Icyeh graduated with a Master degree in ecology from the university, he returned to Smangus and now is in charge of the ecotourism business and work closely with the teachers and students in school at God Village for culturally responsive teaching and curriculum development. Lahuy Icyeh shared with me his responsibilities:

I am a very busy man. Some time, I have to take a group of students for overnight stay in the forest to learn about Tayal traditional hunting and bamboo harvesting skills. My other busy schedule is managing the tourism development project. We are building more guesthouses for tourists so they come can stay for weeks to months out here in Smangus (Personal Communication, April 2016).

Lahuy Icyeh's work have so much impact to his community and the outsiders. It promotes the passing on the Tayal tradition to the next generation, while also promoting tourism.

Elder Masay Sulong shared that over seven years ago, the government was proposing to build a hydropower plant on Smangus land. The Smangus community opposed the project, so they fought and won. He said the Smangus community would get a share of the revenue profit from the hydropower plant, but the plant would be harmful to the ecosystem and environment. The Smangus community would no longer enjoy the beauty of nature, so they rejected the proposal. The government backed off their proposal.

All the eight Elders appreciate the government efforts to recognize the Taiwan Indigenous Peoples and cultural values, but they feel more work need to be done by the government. These Elders are looking forward to the elected Taiwan President Tsai Ing-wen and her administration to allocate more resources to Indigenous communities. Elder Donaiy Dili shared his view on elected President Tsai Ing-wen:

President elected Tsai Ing-wen has a part of the Aboriginal blood in her system. I hope she is seriously about restoring Indigenous cultural values because she made a promise during her campaign when she was running for president. She has some blood from the Paiwan Tribe and the Paiwan people face similar struggles as to Tayal people or any other Indigenous tribes in Taiwan. We like the school to put one hundred percent commitment to help Indigenous children learn their language and culture. Beside school, other government agencies would need to do the same. This way, Indigenous children do not have to suffer from losing their native language and heritage language. I was a retired police officer. I worked for the law enforcement for over seventeen years. Now, I am a Tayal language and culture teacher. I go around to several schools in a week to teach Tayal culture. I am only here to teach at Ching An Elementary School of Miaoli County one day to two days a week and it is not enough. The kids need a teacher to be here more days (Personal Communication, May 2016). See picture 5 


\section{Picture 5: Teacher Donaiy Dili stands in front of his classroom at Ching An Elementary School.}

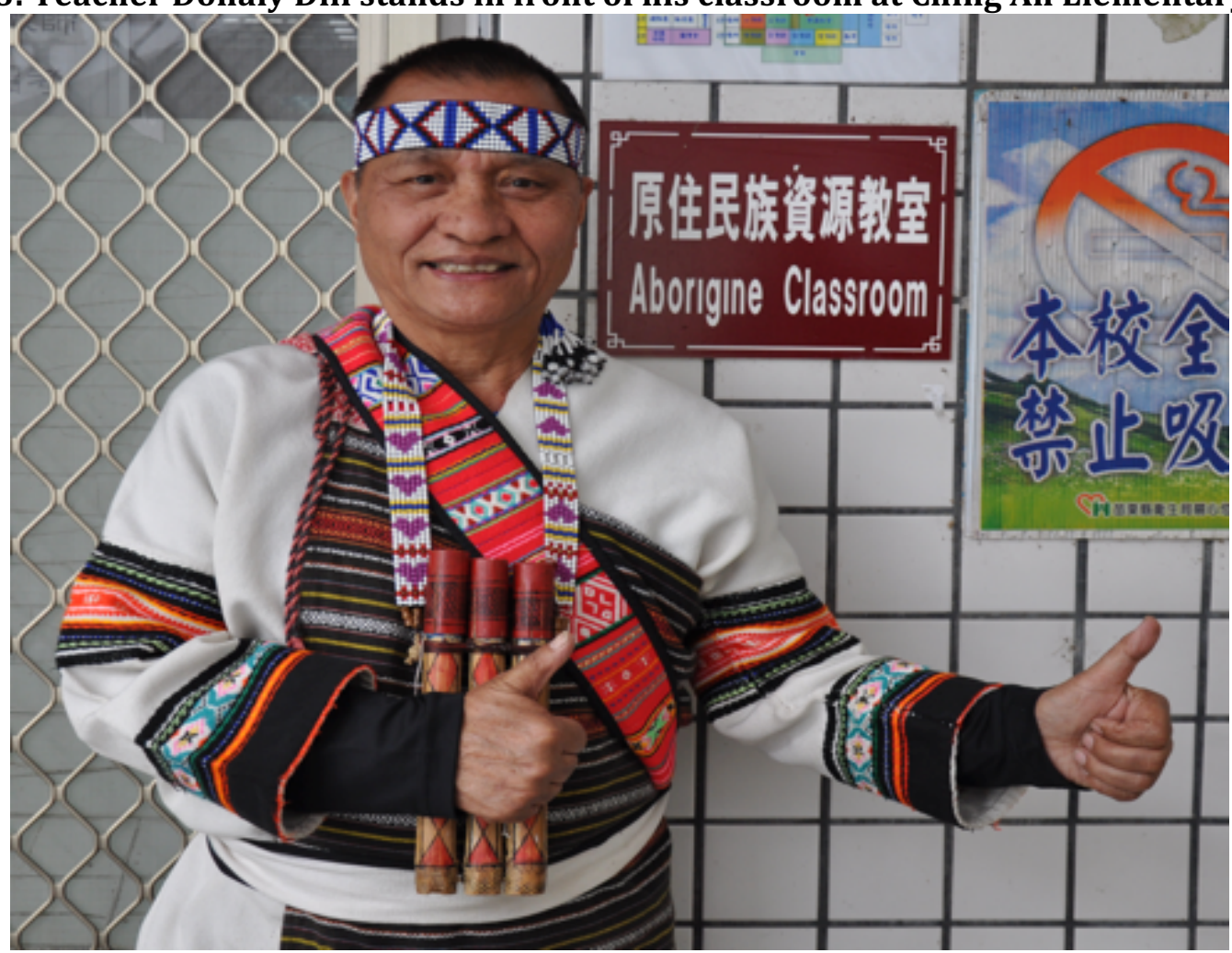

Besides in elementary education, there are indigenous studies programs in the university (See picture 6) and many indigenous museums such as Shung Ye Museum, Wulai Atayal Museum, Maioli Culture Park, Taiwan National Prehistory Museum, etc., Taiwan Indigenous Television Station channel 16, and the Indigenous Peoples Magazine are dedicated to collect resources, preserve and educate about Taiwan Indigenous Peoples.

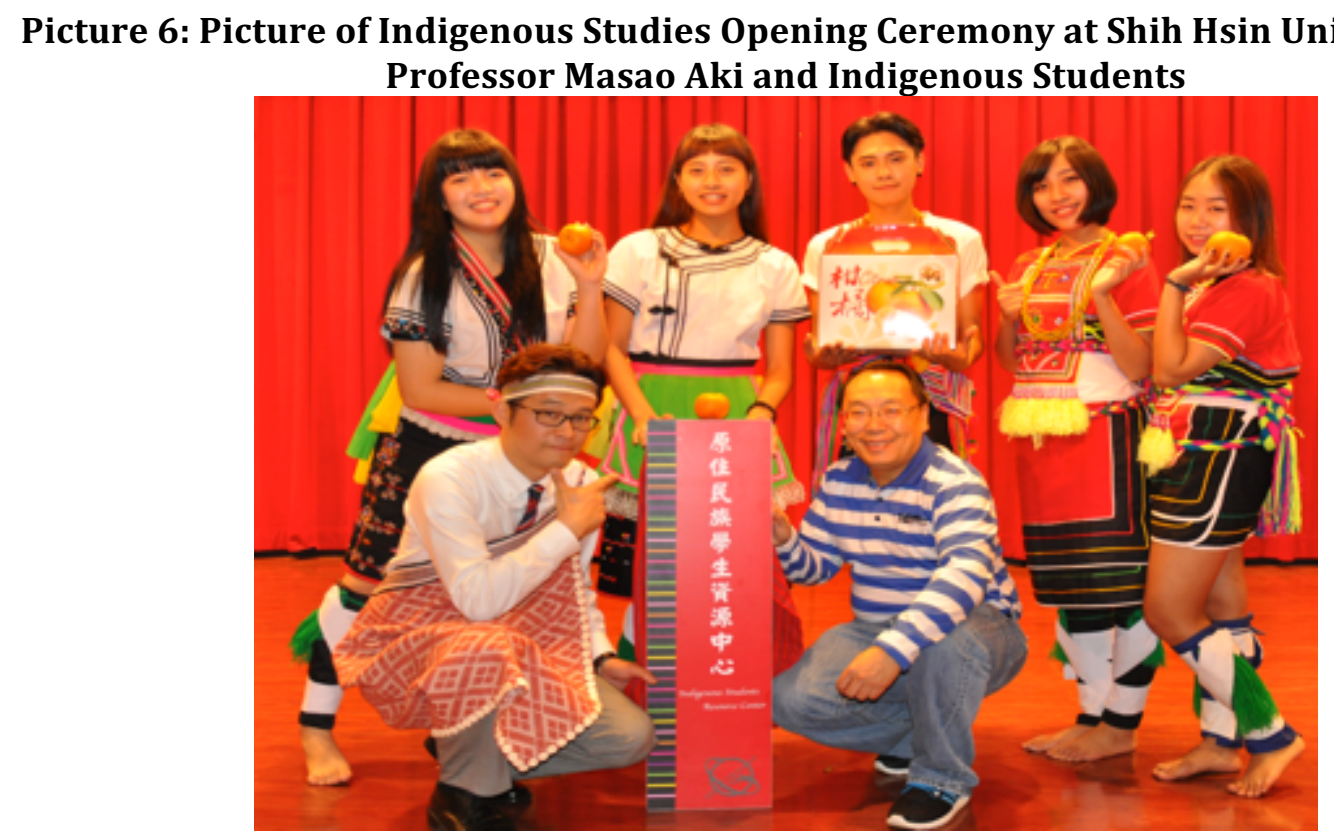

The Elder raised their concerns that even though there are programs devoted to the Indigenous Peoples, not many Indigenous members know how to get access to all the resources. They would prefer to see these programs work like a two-way street where the programs can link directly to Indigenous communities as an educational pipeline preparing 
Indigenous children. They would like to see more authentic cultural programs rather than just the cultural abstract and exploitation of Taiwan Indigenous Peoples. They would prefer to see Indigenous children and Taiwanese children to have real hands on and comprehensive, creative learning experience. Elder Watan Tanga shared his point of view:

I consulted with the Ministry of Culture in Taipei to seek for ways to bring truthful and meaningful Tayal cultural tradition to the educational area. My skills as a Tayal oral traditional song and flute artist, basket weaving and Tayal traditional house builder model, I see that young people can easily learn these things from the Internet or by watching television but they are not as pure/real to them as learning from a person. I am trying to help the government understand real Tayal teaching and learning methods (Personal Communication, May 2016). See picture 7

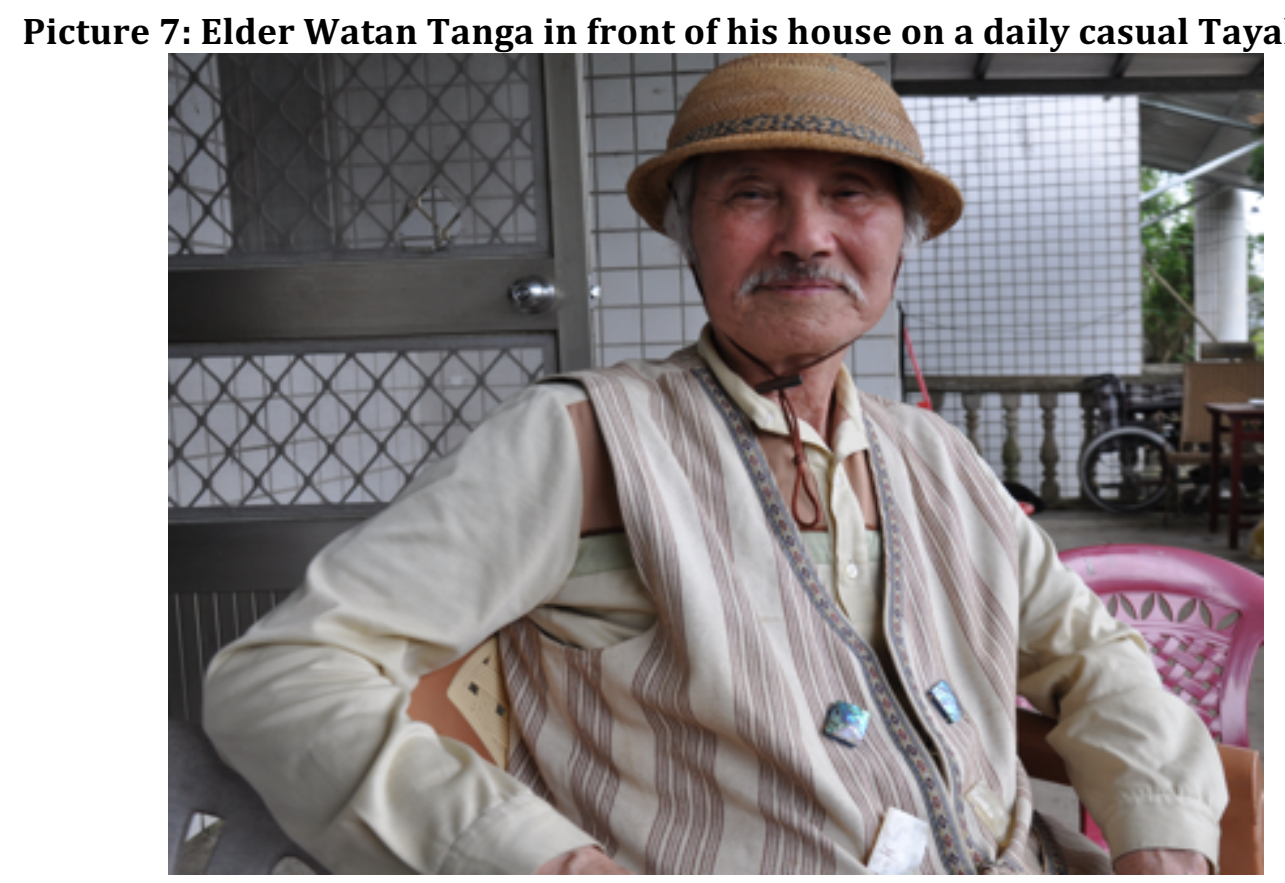

The Elders expressed that they have to learn how to let go of some of their traditional cultural practices. Many people outside the Tayal communities do not understand some of Tayal traditional culture practices and place negative views on them like the Tayal facial tattoos. Today, Tayal people no longer have tattoos on their face for both the men and women. These tattoos symbolize braveness, skillfulness, and honor to the Tayal people. The Tayal people have to work hard in order to earn the tattoo proving their professionalism like the men's hunting skills and women's weaving skills. A Tayal who had a facial tattoo receives the highest honor and respect in the community. Also, it puts him/her in an attractive position for getting a good spouse. Elders Lawa Toyu and Iwan Kaynu are the only two women still living in Miaoli and Taoyuan Counties that have tattoo on their face. Elder Lawa Toyu expressed that the young people of today no longer can perform the tasks that she used to do when she was young. She shared her story:

I will not grant a facial tattoo to the young people of today. They do not know the basic skills to take responsibility in the family or/and in the community. When I was a teenager I knew how to do more things then they can today. I got my tattoo when I was eighteen years old. After we got married, my husband went to the war, and he was killed. This was during the time the Japanese people were here in our land and tried to take control of my people. My customary is that after my husband was killed, I remarried to my husband's younger brother. My husband's family does not want to lose me because I am good woman. The tattoo on my face shows to the community 
and Tayal people that I am a hard worker and a skillful woman (Personal Communication, May 2016). See Picture 8

Picture 8: Elder Lawa Toyu taken inside her house.

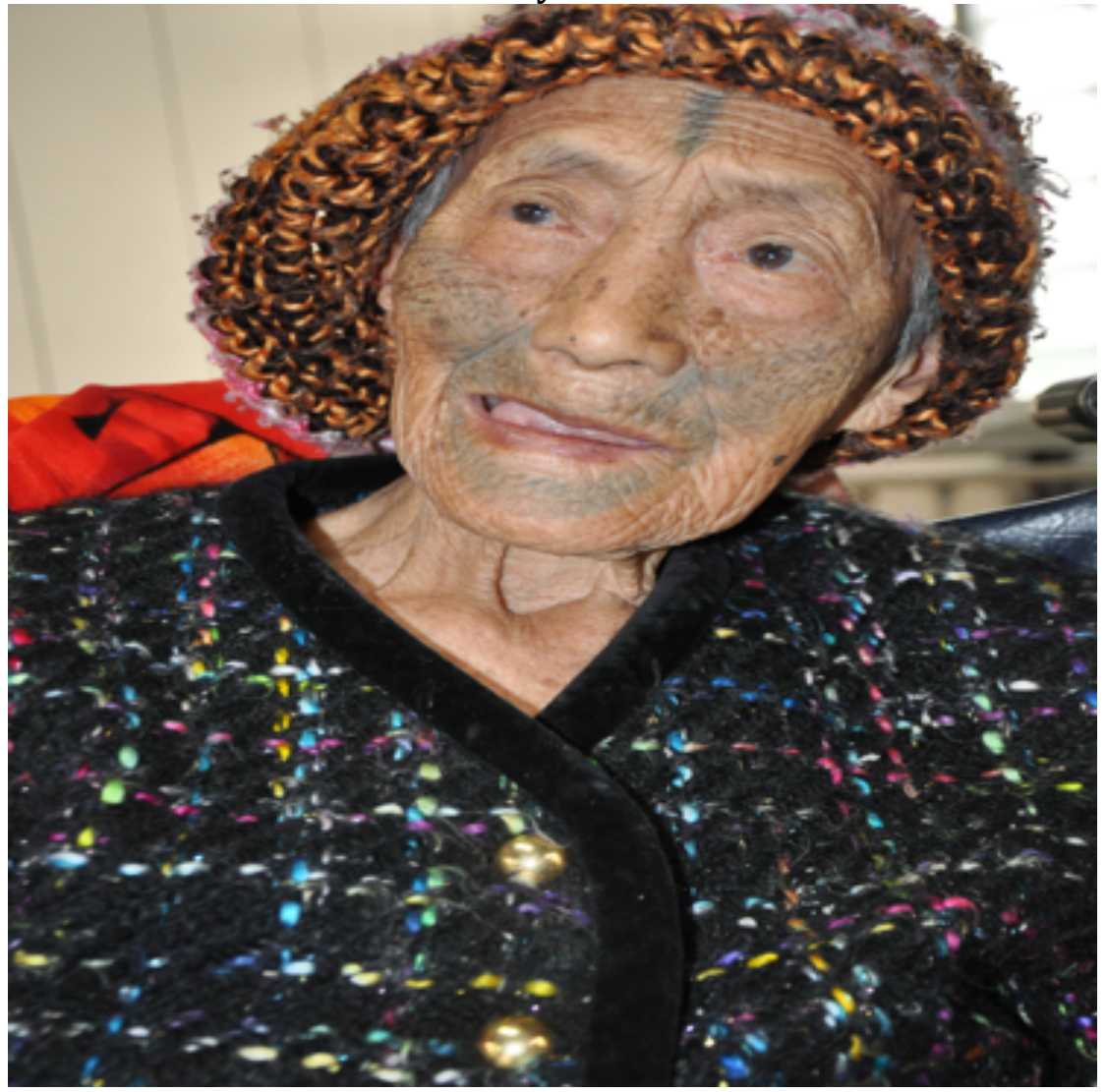

Perceptions on the Impact of Technology. The technology culture is amazing in the Taiwan society. When I was on the Taiwan Metro Rail Train (MRT) or waiting at the public bus stop, I see every person is busy with his or her smart phone or technology gadget. The free access to Wi-Fi in Taipei, malls, and restaurants outside of Taipei areas makes Internet service accessible and very convenient to all Taiwanese. See picture 9.

Picture 9: Inside of a MRT in Taipei, Taiwan

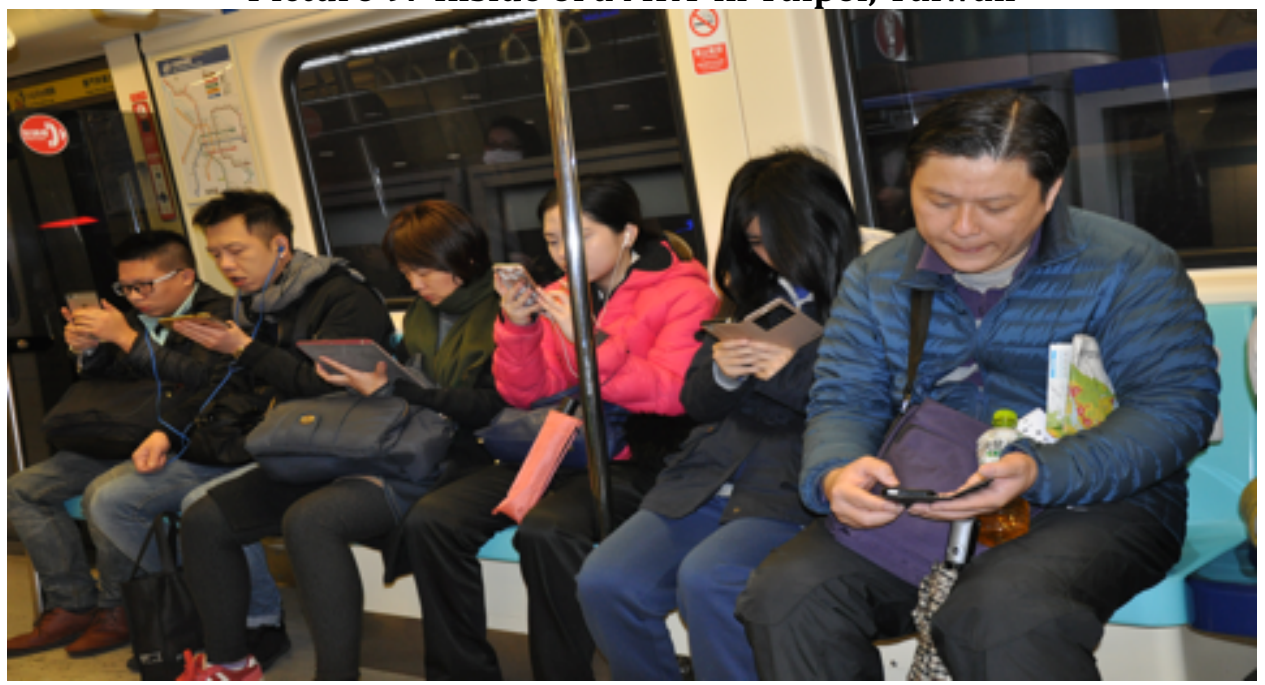


Besides that, the Taiwan Public Television and Taiwan Indigenous Television channels are the most important media outlets to educate Taiwanese about the culture of Taiwan Indigenous Peoples. Professor Masao Aki explained:

I believe that technologies are one quick and best way to educate Taiwanese and Aboriginal children about Aboriginal cultures. My past work with the Taiwan Indigenous Television was to make sure to have programs about Indigenous peoples and air them to educate the world. As a professor, I continue to use social media to promote Indigenous cultural values. My students are using media to learn and educate others about Indigenous peoples (Personal Communication, April 2016).

However, all the Tayal Elders expressed that technology can be very easy for people to have access to information, but it can become very distracting and dangerous. The information people have access to on the Internet sometime is not authentic or accurate. Elder Wagin Sulong shared her concerns about the way young people are using technology:

of course, technology is very convenient for people to get information but the way I see young people use technology today is to play games and communicate with friends. They are not using technology to learn about my culture. They are too busy texting friends and playing games. They are wasting too much time with technology and have no time to learn the Tayal language and culture. When I grew up we did not have smartphone and computers so I stayed close to my parents and elders to learn my culture (Personal Communication, March 2016).

All the Tayal Elders expressed that young people are easily distracted by technology because every young people have a smartphone and always busy touching their phone. The Elders do not know what the young people are doing in the phone. The young people just cannot let go the phone for a second without listening to music or just touching the phone. An Elder pointed out that it seems like people of today cannot stay away from their smart phone for a minute. Donaiy Dili and Masay Sulong are the two Elders that use their smartphone for texting and social media purpose. Elder Wagi Sulong has a smartphone but she only uses it to make calls. Elder Masa Tohuy, Wanta Tanga, Tayax Behuy, Lawa Taoyu and Iwan Kanyu only use analog phone.

According to the two Graduate Students and the professor, technology is so reliable and a fast way to get information. Although, Lahuy Icyeh said he hardly use the Internet on his phone rather than just make calls. He feels that it requires a lot of time consuming when you text or surf on the web and of course is very expensive to pay for the service, especially in Smangus at God Village.

Seven Elders are extremely concerned about how the technology culture would to do prevent Tayal young people and children from maintaining the Tayal cultural tradition. They see that the young people and children have so many opportunities like school, jobs, sports, and technology. It gives them no time to involved in their community to study Tayal language and culture. Tayal language and culture require a lot of time spending with the elders to learn the language and cultural practices like rituals, songs, weaving techniques, hunting skills, etc. Elder Wantan Tanga shares his concerns:

Young people and children of Tayal believe and see that their traditional cultural skills are no long applicable to this $21^{\text {st }}$ century. Therefore, they want to concentrate on the skills and knowledge that can help them to get a good paying job or be good at school (Personal Communication, March 2016).

Therefore, the Elders are having mixed feeling about the way technologies are handle by the young people. One Elder commented that in a sense, it can be a tool to help young people 
connect around the world and get fast information on different things. However, if young people do not know how to use it in an efficient way then it will get them into trouble.

Perspectives of Religion Belief. The Tayal communities I visited had converted their ancestral religion from Utux, often referred to as animism, into Christianity. Even though Christian faith has become very popular and important to Tayal, they still hold strongly to their Gaga justice system. The Tayal people's view of Christianity seems very positive. An Elder explained that the Tayal people no longer know how to perform the ritual of the Utux and the Tayal people always have bad luck bringing sickness and death to the communities. It was a curse that happened to the people. When the Christian missionary came to their communities, the missionary brought medicines and cloth to the Tayal people. The medicines helped the Tayal people from being sick and dying. Then, the Tayal believe that Jesus is the spirit of Utax. Perhaps we see syncretism at work here. This is the reason why the Tayal people are now Christian. Elder Tayah Behuy shared a story:

They gave us the medicine to care for our sickness, protect our health and we believed this brought us good prosperity. We worship the Utux for the same purpose. Since, we no longer know the proper way to practice our ritual ceremony of the Utux, we go to church and God will protect us (Personal communication, April 2016).

Elder Masa Tohuy also shared his memory about his religion and Christianity.

I am Christian. The Christian missionary came into contact with my family in 1948 . This is when I became a Christian. For these last few years the Christian faith is flexible to have us practice the value of Gaga, which it is a good thing for our people. Before that, Christianity was very strict about our traditional belief (Personal Communication, May 2016).

The Tayal young generation has very little exposure to the traditional Gaga or Utux system because they are extremely busy in school and Bible studies at church. The two graduate students expressed how much they missed out from their traditional culture and religion in education. They remember going to school on weekdays to learn Mandarin Chinese and that the weekend is for church. There was no time to observe Gaga or Utux rituals at home.

They said the school curriculum that they studied was only about the culture norms and values of the Chinese people. It had nothing to do with the languages and culture of Tayal people. Wasing Silan described her experience:

I grew up studying only Han Chinese culture values and speaking Mandarin. At school, I did not remember studying anything about Indigenous people. Now as a graduate student, I am doing my research on the Tayal health care issues for my dissertation. I learned so much from it. I missed all the things in my early education, which is the important of Tayal language and culture. Now, I am currently studying my Tayal language. I did not speak Tayal when I grew up, so I am learning it. It was a wonderful experience (Personal Communication, March 2016).

The Elders observe similar issues surrounding Tayal children of today because of school works and technology influences separating them from being close to parents and elders to learn Tayal tradition. Also, Tayal children will focus on Christian faith, which was not about Gaga and Utux. However, two Elders expressed that recently they are happy to see pastors begin using the concept of Tayal Gaga with Christian faith in seminar. This is very good news because Christian faith allows Tayal tradition to be part of their religious belief. 
Every Tayal community I visited has a church for the community to go worship. At church, they study the Bible and it is a belief of replacement for the moral principles of Tayal Utux belief. I attended a Tayal wedding service at Smangus in a church. After that, I went to have a traditional meal plus ritual at the groom's home. Also, I attended the Sunday church service at Colen community when I visited an Elder for the interview and ended up staying overnight. I witnessed that the church brings the community close to one another by believing in Christian faith. I observed that the Bible was written in Mandarin on the first half and the second half was a written translation of RPA script. I was wondering whether the church teach the RPA to young people so they can keep the Tayal language.

Themes Responses, Figure 1 below was an explanation of frequent responses from the research participants based on six theme topics. It indicates that themes of Christianity belief and education/school have the highest total responses (11). The theme category of traditional culture system values got eight, which were mainly from the Elders. The theme "identify strongly as a Tayal through language and culture identity received ten. The two lowest responses were on technologies influences and government resources (5). These responses clearly showed that there is a generational gap between traditional and modernized culture values. The Elders were skeptical about an effort to continuously maintain Tayal language, custom, and culture tradition after their generation dies out due to the influences and pressures of modern and outsider cultures. A professor and the two graduated students are at a critical time in this modern society. They are very important educators who will serve on a role as Tayal language and culture negotiator and advocate. Their role model and services will be like a bridge to connect between the Tayal and Taiwanese society and continue to inspire Tayal children.

Figure 1: Total frequent responses of Strong to Least Favor related to the 6 Themes from 11 research participants.

\begin{tabular}{l}
\multicolumn{1}{l}{ Themes } \\
\begin{tabular}{|l|c|c|c|c|}
\hline Traditional culture system values & 8 & 0 & 0 & 8 \\
\hline Christianity belief & 8 & 1 & 2 & 11 \\
\hline $\begin{array}{l}\text { Identify strongly as a Tayal and } \\
\text { maintain a language and culture } \\
\text { identity }\end{array}$ & 8 & 1 & 1 & 10 \\
\hline Education/School & 8 & 1 & 2 & 11 \\
\hline Technology influence & 2 & 1 & 2 & 5 \\
\hline Government resource & 4 & 1 & 0 & 5 \\
\hline
\end{tabular}
\end{tabular}

\section{CONCLUSION}

This study concluded that the Tayal Elders are extremely concerned about losing their language and culture heritage due to the effect of global Capitalism and the forces of modernization. The Tayal traditional culture and forest become a commercial icon for Taiwan's tourism industry. A major priority is to save the Tayal language so they can continue to enjoy the music, art, crafts, and oral poetry song "Lmuhuw". Traditional musical instrument, Jew's Harp, weaving techniques for basket and clothing, textile, oral traditional songs, and ceremony songs are key symbols and indices of the values of Tayal culture and identity. School is the center of a community. School needs to become a place where Tayal old and 
young generations feel welcome and comfortable to teach, learn and share their language and culture, collaborate with school administrators and teachers to organize social events, and have input on curriculum materials. School must be able to effectively leverage multicultural resources for all diverse students. This kind of school can be designed in any Taiwanese community with a large Tayal population and be in an inner city or rural environment, as long as the staff, teachers, and administrators set a high priority for working with and supporting Tayal children in education.

Furthermore, it is necessary for the Taiwan government to affirm an equal opportunity access employment policy for people from bilingual and bicultural background. This equal opportunity employment policy will encourage all stakeholders to promote and value language and culture diversity. Therefore, it is necessary to empower all levels of stakeholders from government officials such as legislatures, law enforcement, healthcare organizations, schools, and parents in all communities in Taiwanese society to embrace for language and culture diversity.

Since traditional knowledge and skills are no longer recognizable in modern Taiwan society (Fang, Hu and Lee, 2016; Hu, H., Tseng, R., Lin, C., Ming, L., \& Ikeuchi, K., 2014; Shih, 2010; Gluck, 2005), it is a huge hurdle for Tayal parents to teach traditional language, culture and knowledge to children without cooperation from the government, public and private entrepreneurs. Together, Taiwanese society will be a stronger multicultural nation with the knowledge learned from past, present and future cultures. Researchers Tang and Tang (2010) and Sheu and Huang (2014) reminded us that the Tayal tradition of the Gaga justice model can be worthwhile to consider as future improvement for the criminal justice system in Taiwan.

As mentioned above, to construct an authentic Tayal traditional culture program in schools where both Tayal elders feel empowered to educate Tayal and Taiwanese born children is an asset for Taiwan multicultural education in this $21^{\text {st }}$ century and onto future generations. It prepares the citizens of the Taiwan peoples to appreciate language and culture diversity as a nation rather than with something resembling resentment. Modern Taiwanese society has a potential to become a strong multicultural and multilingual nation under new President Tsai Ing-wen and her administration. A cultural diversity celebration from different Taiwan Indigenous tribes during President Tsai Ing-wen inauguration on May 20, 2016 demonstrated for a new beginning of Taiwanese future.

\section{References}

Agar, M. H. (1996). The professional stranger. San Diego, CA: Academic Press. Inc.

Blundell, D. (Eds. 2012). Taiwan since martial law: Society, culture, politics and economy. Berkeley, CA: University of California Berkeley and National Taiwan University Press.

Cajete, G. (1994). Looking to the mountain and ecology of indigenous education. Durango, CO: Kivaki Press

Chai, C. K. (1967). Taiwan aborigines: A genetic study of tribal variations. Cambridge, MA: Harvard University Press

Chen, W. P. (2007). Once upon a time [DVD]. Available from Shei-Pa National Headquarters. Fusing Village, Ta-Hu Township, Maioli County, Taiwan, R.O.C.

Cresswell, J. W. (2013). Qualitative inquiry and research design: Choosing among five approaches ( ${ }^{\text {rd }}$ ed.). Thousand Oaks, CA: Sage.

Digital Museum of Taiwan Indigenous People (2016). Atayal. Retrieved www. ATAYAL SOURCES/Digital Museum of Taiwan Indigenous Peoples.html

Keating, J.F. (2011). The mapping of taiwan: Desired economies, coveted geographies. Taipei, Taiwan: SMC Publishing Inc. 
Kuan, D. (2009). A river runs through it. Story of resource management, place identity and indigenous knowledge in Marqwang, Taiwan (Unpublished Dissertation). University of Hawai'i, Hawaii, USA.

Kun-hui, K. (2012). Rights to recognition: Minorities and indigenous politics in emerging Taiwan nationalism. In D. Blundell (Eds.), Taiwan Since Martial Law: Society, Culture, Politics and Economy (pp. 91-130). Berkeley, CA: University of California Berkeley and National Taiwan University Press.

Fang, W. T. Hu, H, W, \& Lee, C. S. (2016). Atayal's identification on sustainability: traditional ecological knowledge and indigenous science of a hunting culture. Sustainability Science, 11(1), 33-43.

Fang-Ming, C. (2015, Editor). The anthology of taiwan indigenous literature (part I \& II). Taipei City, Taiwan: Council of Indigenous People.

Gluck, C. (2005, July 4). Taiwan's aborigines find new voice. BBC Taiwan

Hose, A., Schaub, J. \& Bremer, C. (2010). Voices in the clouds [DVD]. Available from Atayal Non-profit Organization. Fern Park, FL:

Hsiao, H.C. 2008, April). "Ecology" and indigenous political and cultural struggles in Taiwan: a case study of two atyal village. Paper presentation at The Fifth EATS Conference, April 18-20, 2008. Prague, Czech Republic.

Hsiao, N. (2016, March 20). A year in the clouds [Television broadcast]. Taipie, Taiwan: Public Television Station

Hu, H., Tseng, R., Lin, C., Ming, L., \& Ikeuchi, K. (2014, November). Analyzing taiwanese indigenous folk dances via labanotation and comparing results from interdisciplinary studies. In Euro-Mediterranean Conference (pp. 196206). Springer, Cham.

Huang, L.M. (2002). Nominalization in mayrinax atayal. Language and Linguistic, 3(2), 197-225.

Lee, J. (2013). A fieldwork report on Atayal language spoken in Wulai. (Unpublished master's thesis). National Chengchi University, Taipei, Taiwan.

Lin, Y.R. (2008). Tayal traditional ecological knowledge. Maioli County, Taiwan, R.O.C.: Shei-Pa National Park Headquarters

Mebow, L. (2016). I love lah laqi [Motion picture]. Available from Sky Films.

Rau, D. H. V. (1992). A grammer of atayal (Unpublished dissertation). Cornell University

Munsterhjelm, M. E. (2004). Aborigines saved yet again: Settler nationalism and hero narratives in a 2001 exhibition of Taiwan Aboriginal artifacts. (Unpublished master's thesis). University of Victoria, Victoria, Canada.

Reid, D. C. (2010). Indigenous Rights in Taiwan and the Smangus Case [available online at: nccur. lib. nccu. edu. tw/bitstream/140.119/50049/1/401602. pdf, accessed 08. 06.2015]. International Masters Program in AsiaPacific Studies, College of Social Sciences. Taipei: National Chengchi University.

Shih, C. F. \& Wu, P. I. (2008). Indigenous people and co-management of natural resources. Paper presentation for the International Peace Research Association Global Conference "Building Sustainable Futures: Enacting Peace and Development”. University of Leaven, Belgium. July 15-19.

Shih, C. F. (2010). Academic colonialism and the struggle for indigenous knowledge system in Taiwan. Social Alternatives, 29(9), 44-47.

Sheu, C.J. \& Huang, H. F. (2014). Restoration justice in Taiwan's aboriginal socieities: the example of the atayal tribe. Restorative Justice, 2(3), 260-279.

Shung Ye Museum of Formosan Aborigines (1999). The life of Taiwan's indigenous peoples [DVD]. Available from Shung Ye Museum of Formosan Aborigines. Taipei, Taiwan.

Smith-Tuhiwai, L. (2012). Decolonizing methodologies research and indigenous peoples. New York, NY: Zed Books Ltd.

Tang, C and Tang S. (2010, February). Institutional adaptation and community-based conservation of natural resources: The cases of the tao and atayal in Taiwan. Human Ecology, 38(1), p101-111.

Thao, Y. J. (2006). The Mong oral tradition: Cultural memory in the absence of written language. Jefferson, NC: McFarland \& Company, Inc., Publisher.

Thao, Y. J. (2014). Oral culture amidst the diversity of modern american society. Advances in Social Sciences Research Journal, 1(2), 99-104.

Yen, A. C. \& Chen, Y.A. (2013). Self-governance on indigenous community for sustainability development: A case study in Tayal community in Taiwan. International Journal Sustain Development, 6(2), 55-70. 
Yoshimura, M. (2007). Weaving and identity of the atayal in wulai, taiwan (Unpublished master's thesis). University of Waterloo, Waterloo, Canada.

Yoshimura, M., and G. Wall (2010), "The Reconstruction of Atayal Identity in Wulai, Taiwan." in Heritage Tourism in Southeast Asia, M. Hitchcock, V. King and M. Parnwell (eds.), Copenhagen: NIAS (Nordic Institute of Asian Studies) Press, 49-71.

Wang, I. C. (2012). The de/construction of heroes: A case study in a atayal village in Taiwan. Paper presentation for the Asian Conference on Asian Studies, Oska, Japan. 